\title{
NEW FIND OF ZUNYITE IN ADVANCED ARGILLIC ALTERATION OF RHYOLITES, KOS ISLAND, SOUTH AEGEAN VOLCANIC ARC, GREECE
}

\author{
Papoulis D., Tsolis-Katagas P. and Katagas C. \\ Department of Earth Materials Geology, School of Geology, University of Patras, Patra, 26500 , \\ Papoulis@upatras.gr
}

\section{ABSTRACT}

Zunyite $\left[\mathrm{Al}_{13} \mathrm{Si}_{5} \mathrm{O}_{20}(\mathrm{OH}, \mathrm{F})_{18} \mathrm{Cl}\right]$, an extremely rare mineral, was found as an accessory mineral in highly altered rhyolitic rocks at Kefalos, southwestern Kos, and in a completely kaolinized rhyolitic dyke at Asfendiou, northeastern Kos. It is associated with dickite, kaolinite, quartz and minor pyrophyllite. Kos Island contains both Tertiary and Quaternary volcanic rocks.

Zunyite has been identified by XRD and studied by SEM, EDS, Raman spectroscopy and FTIR spectroscopy. The presence of zunyite, in the highly altered samples is significant for the determination of the conditions of the hydrothermal alteration that took place.

Zunyite crystals, are up to $90 \mu \mathrm{m}$ in diameter but usually are less than $10 \mu \mathrm{m}$; the crystals are partly covered by kaolinite layers. $\mathrm{EDX}$ analyses on the surface of zunyite revealed $\mathrm{Al}_{2} \mathrm{O}_{3} / \mathrm{SiO}_{2}$ values raging from 2.6 to 2.7 .

The occurrence of zunyite suggests incorporation of hydrothermal fluids rich in $\mathrm{F}^{-}$and $\mathrm{Cl}^{-}$, thus indicating contamination by seawater.

\section{INTRODUCTION}

Zunyite $\left[\mathrm{Al}_{13} \mathrm{Si}_{5} \mathrm{O}_{20}(\mathrm{OH}, \mathrm{F})_{18} \mathrm{Cl}\right]$ is an extremely rare mineral, which is generally found either as an alteration product of feldspars in silicified igneous rocks, as a gangue in metalliferous veins or as an alteration product in advanced argilic alteration.

The mineral zunyite $\left[\mathrm{Al}_{13} \mathrm{Si}_{5} \mathrm{O}_{20}(\mathrm{OH}, \mathrm{F})_{18} \mathrm{Cl}\right]$ was originally described together with guitermanite, a sulfide of lead and arsenic nowadays known as jordanite, from the Zuni mine on Anvil Mountain, Silverton, San Juan Country, Colorado and named for the Zuni mine (Kloprogge \& Frost 1999). Zunyite, is an extremely rare mineral, characteristic of certain hypogene hydrothermal assemblages, forming in a narrow range of physical conditions of temperature and pH (Inoue 1995). It possesses not only an unusual combination of an $\mathrm{Al}_{13} \mathrm{O}_{16}(\mathrm{OH})_{24}$ Keggin structure and a $\mathrm{Si}_{5} \mathrm{O}_{16}$ pentamer unit first established by Pauling (1933), but it is also one of the few minerals containing as many as three different volatile components, viz $\mathrm{H}_{2} \mathrm{O}, \mathrm{F}$ and $\mathrm{Cl}$ (Louisnathan \& Gibbs 1972). The $\alpha$ Keggin unit of zunyite is fluorine-substituted in the intertrimeric $\mathrm{O}(4)$ site, leading to the creation of crystallographically unequivalent sites for fluorine and lowering the symmetry of the central tetrahedral site (Zhou \& Sherriff 2003). The issue of Al:Si order has been a topic of controversy for many years. Zagal' skaya \& Belov (1964) suggested that Si should be in the center of the Keggin structure. Refinements of Louisnathan \& Gibbs (1972) and Baur \& Ohta (1982) disproved this arrangement, but showed that excess Al could be accommodated in the center of the pentamer.

The presence, in trace amounts, of alunite, in highly altered rhyolitic rocks at Kefalos, a mineral much more common than zunyite in hydrothermally altered formations, indicates that the hydrothermal fluids were poor in $\mathrm{S}^{-2}$.

The mineral zunyite is so rare in nature that any information regarding a new occurrence seems worthy of record. 
The mineral zunyite was found as an accessory mineral in highly altered rhyolitic rocks at Kefalos, southwestern Kos, and in a completely kaolinized rhyolitic dyke at Asfendiou, northeastern Kos (Fig. 1). It is associated with dickite, kaolinite, quartz and minor pyrophyllite. Kos Island contains both Tertiary and Quaternary volcanic rocks. The Quaternary volcanism produced a successive series of rhyolitic-dacitic volcanic rocks and pyroclastic flows (Boven et al. 1987, Dalambakis 1987). The kaolin occurrences of the Kefalos peninsula, SW Kos Island, are associated with rhyolitic rocks of Pliocene age (Boven et al. 1987). These rocks exhibit perlitic texture and are composed of quartz, Na-plagioclase, K-feldspar and volcanic glass. The kaolin occurrences are generally white in colour, but frequently are also stained reddish by iron oxides; they extend over an area of about $0.5 \mathrm{~km}^{2}$ (Papoulis \& Tsolis-Katagas 2001, Papoulis 2003). Kaolin occurrences of Asfendiou area are products of hydrothermal alteration of a rhyolitic dyke. The parent rock is almost completely altered but rare remnants occur.
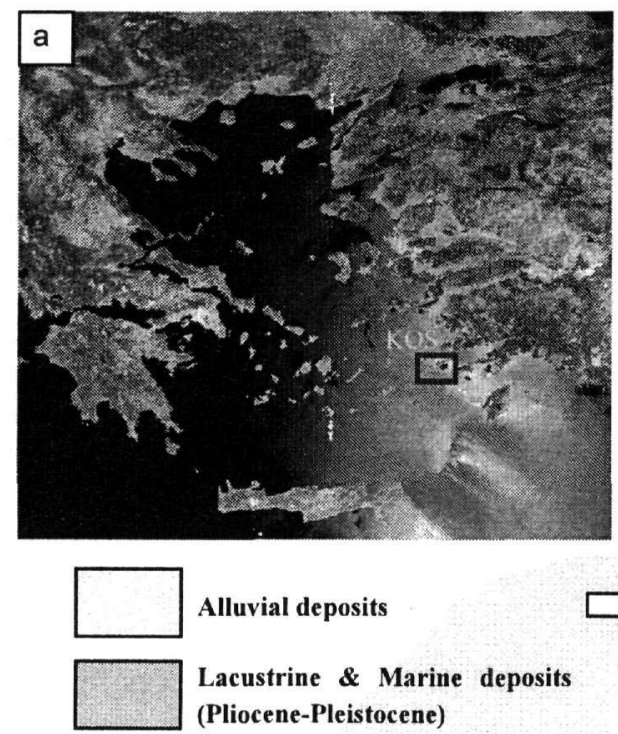

Alluvial deposits
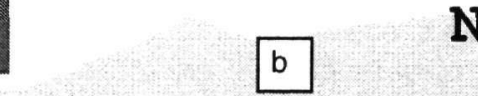

Lactrine \& Marine deposits

(Pliocene-Pleistocene)

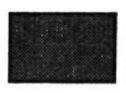

Volcanic rocks, Tuffs, Ignimbrites (TertiaryQuaternary)

$5 \mathrm{~km}$
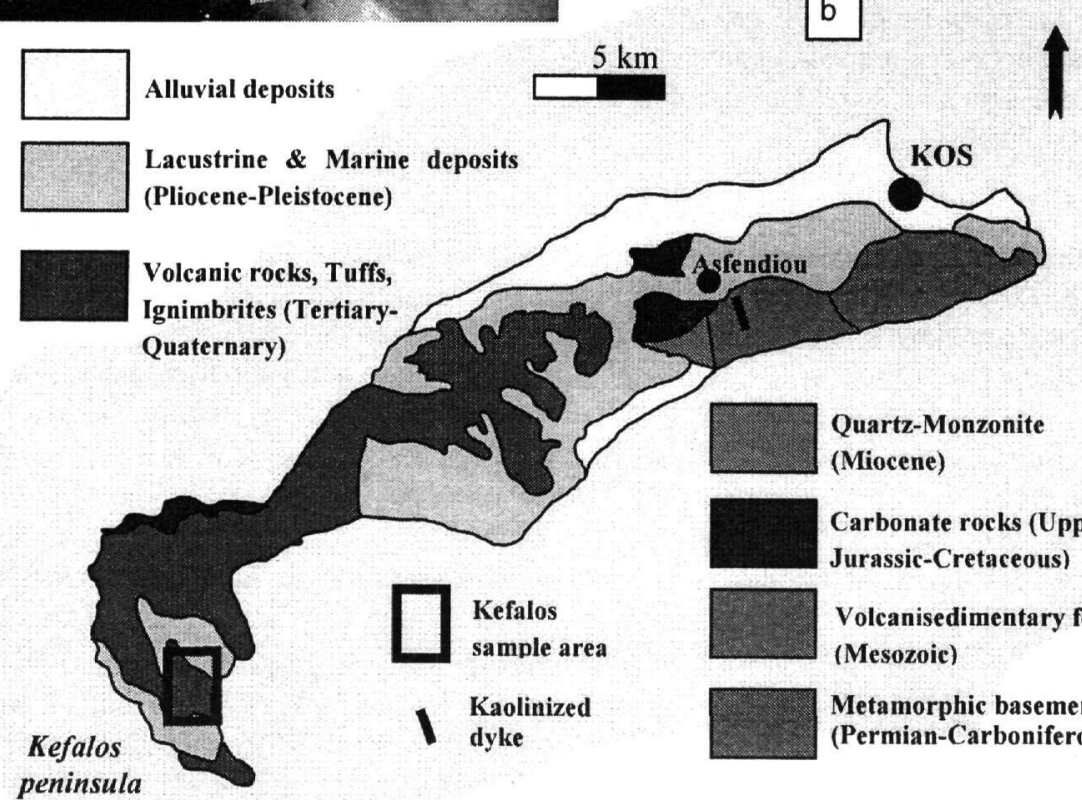

Figure 1. a). Geographic position of Kos Island, in the Southeastern Aegean Sea. b). Geological sketch map of Kos Island (after Triantaphyllis 1994, 1998). 


\section{METHODS}

Mineralogical compositions of bulk rock and of clay fractions $(<2 \mu \mathrm{m})$ of the samples were determined by X-ray diffraction, using a Philips diffractometer PW1050/25, with Ni-filtered CuKa radiation. Powders from oriented clay-aggregate samples were scanned at $1^{\circ} 2 \theta / \mathrm{min}$ from 3 to $60^{\circ} 2 \theta$. Clay minerals were identified from three XRD patterns (air-dried at $25^{\circ} \mathrm{C}$, ethylene-glycolated, and heated at $490^{\circ} \mathrm{C}$ for $\left.2 \mathrm{~h}\right)$ of the clay-size fraction $(<2 \mu \mathrm{m})$ extracted by the standard sedimentation technique in deionized water.

Selected samples were examined under shortwave and longwave ultraviolet light.

Mineral textures, morphology and chemical composition of alteration products were determined at the Laboratory of Electron Microscopy and Microanalysis, University of Patras using a Scanning Electron Microscope (SEM, JEOL 6300) equipped with EDS and WDS spectrometers and a THETA software. The chemical composition of zunyite was determined using EDX analyses.

The FT-Raman spectra were obtained with a power of $3 \mathrm{~mW}$ on the specimen for a total integration time of $12 \mathrm{~s}$; a viewing screen connected to the microscope offered good sample positioning, good laser beam focusing, and direct surface inspection. The scattered light was filtered (HNF514-1.0 from Kaiser Optical Systems), to remove the elastic Rayleigh scattering. The T-64000 (Jobin Yvon) Raman system, equipped with a Spectraview-2D liquid $\mathrm{N}_{2}$-cooled CCD detector was used, in the single spectograph configuration, to disperse and detect the Raman signal. The spectral resolution for the Raman spectra used for molecular orientation was $\sim 5 \mathrm{~cm}^{-1}$. The spectral window was centered at $3600 \mathrm{~cm}^{-1}$ (in the Stokes region). The Raman spectrum has been recorded with the FT-Raman FRA-106-S module of an Equinox 55 FTIR spectrometer of Bruker.

Infrared spectra were measured in the specular reflectance mode on a Bruker vacuum spectrometer (IFS 113v) equipped with a near-normal incidence $\left(11^{\circ}\right)$ reflectance accessory. A KRS-5 wire grid polarizer was positioned before the sample to polarize the infrared radiation perpendicular to the plane of incidence. The polarizer remained fixed and the sample was rotated by $90^{\circ}$ to obtain reflectance spectra with different polarization directions. The reflectance spectrum of a high reflectivity aluminum mirror was measured with the polarizer in place and the same instrument settings and used as reference spectrum. All spectra were measured at room temperature and represent the average of 200 scans at $2 \mathrm{~cm}^{-1}$ resolution.

\section{RESULTS}

Zunyite in the studied areas was recognized from its XRD pattern in highly altered rhyolitic rocks (Figs. 2a, b). Dickite, kaolinite, zunyite and quartz coexist in these highly altered samples. Most of the samples containing zunyite examined under shortwave ultraviolet light fluoresce red. The same samples under longwave ultraviolet light fluoresce in various colours (purple, blue flecks). SEM observations show that zunyite crystals are up to $90 \mu \mathrm{m}$ in diameter (Fig. 3), but usually are less than $10 \mu \mathrm{m}$. Zunyite identification is based on its cubic crystal habit and EDX analyses (Fig. 4). EDX analyses and spectra taken from the surface of zunyite revealed $\mathrm{Al}_{2} \mathrm{O}_{3} / \mathrm{SiO}_{2}$ values raging from 2.6 to 2.7. Its crystals are usually partly covered by kaolinite layers (Figs. 3, 4c, d) and EDX analyses on covered surfaces of zunyite show lower $\mathrm{Al}_{2} \mathrm{O}_{3} / \mathrm{SiO}_{2}$ ratios $(<2.5)$ (Figs. $4 \mathrm{c}$, d), due to the presence of kaolinite.

Representative FTIR spectra of highly altered samples from Kefalos, in the region $400-4200 \mathrm{~cm}^{-1}$ are shown in Fig $5 \mathrm{a}$. In the highly altered samples the position and the relative intensity of the bands, especially in the $\mathrm{OH}$ stretching region, indicate the presence of dickite and minor kaolinite (Fig. 5a). The bands of dickite in the $\mathrm{OH}$ stretching region are not well formed showing poorly ordered dickite. This is also attributed to the presence of zunyite bands $\left(3649 \mathrm{~cm}^{-1}\right.$, Turco 1962,3625 $\mathrm{cm}^{-1}$, Gadsden 1975) in the same area with dickite bands. The other characteristic bands of zunyite 725, $\sim 900,1000, \sim 1176 \mathrm{~cm}^{-1}$ (Turco 1962, Gadsden 1975, Kloprogge \& Frost 1999) overlap with 
the bands of dickite and kaolinite. The FTIR spectra of the highly altered samples of Asfendiou (Fig. $5 b)$ are similar to the highly altered samples from Kefalos.

The FT-Raman spectra of the low frequency region of representative completely kaolinized rocks from Kos, shown in Figs. $6 a$, b confirmed also the presence of zunyite. The band positions $\left(\mathrm{cm}^{-1}\right)$ of zunyite $\sim 200,355,395,520$ and 615 are very close to the positions of zunyite suggested by Kloprogge \& Frost (1999).

In the highly altered samples from Kefalos (Fig. 6a) dickite coexists with zunyite; minor kaolinite is also present. The FT-Raman spectra, in the region $100-1200 \mathrm{~cm}^{-1}$, of highly altered samples from Asfendiou show also the coexistence of zunyite, kaolinite and dickite (Fig. 6b).
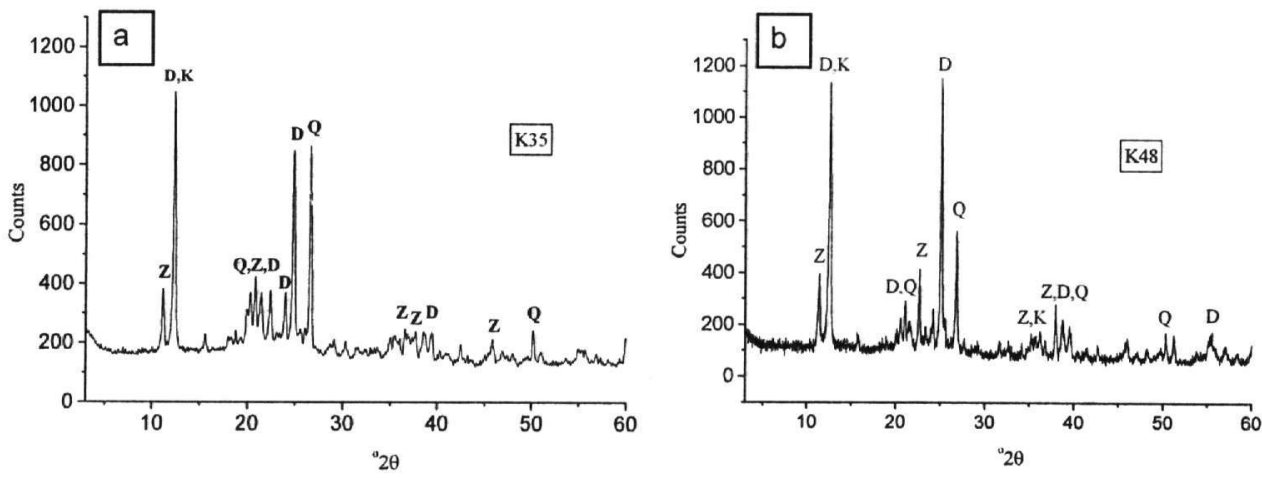

Figure 2. X-Ray powder diffraction patterns of highly altered rhyolitic rocks from Kefalos (a) and Asfendiou (b). $Z=$ Zunyite, $D=$ dickite, $K=$ kaolinite, $Q=$ quartz.
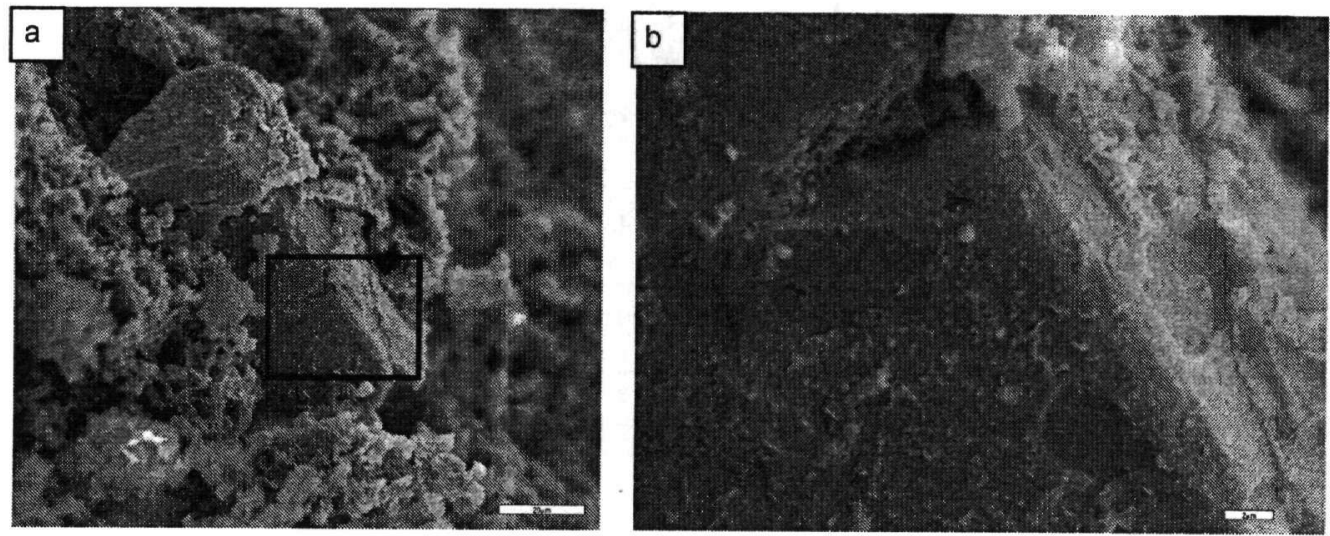

Figure 3. SEM microphotographs of a hydrothermal kaolin sample from Kos. (a) The single crystal in the center is zunyite, (b) Magnification of the box. 

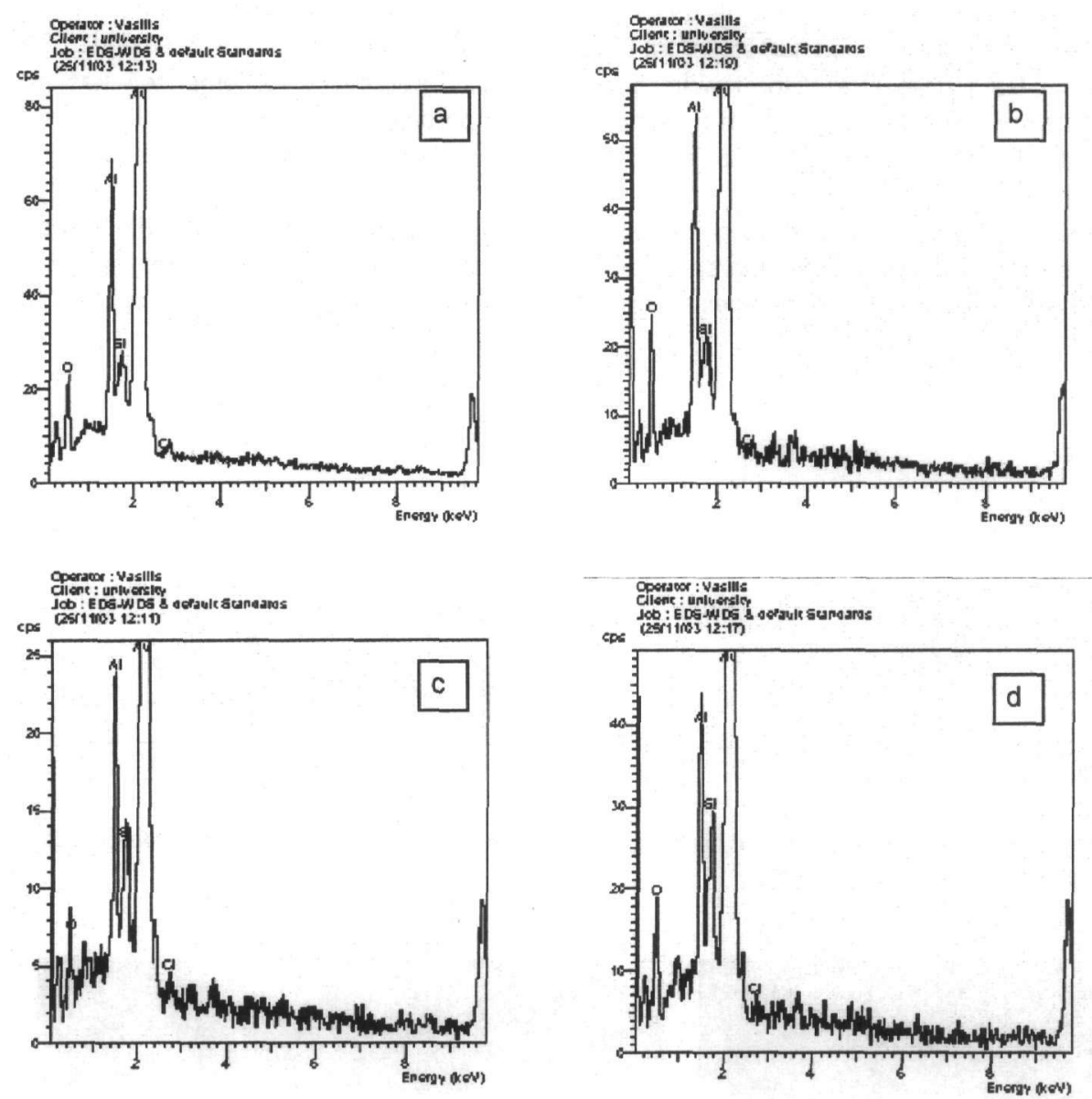

Figure 4. Energy dispersive X-Ray spectra (EDX) of zunyite $(a, b)$ and zunyite crystals partly covered by kaolinite layers (c, d).
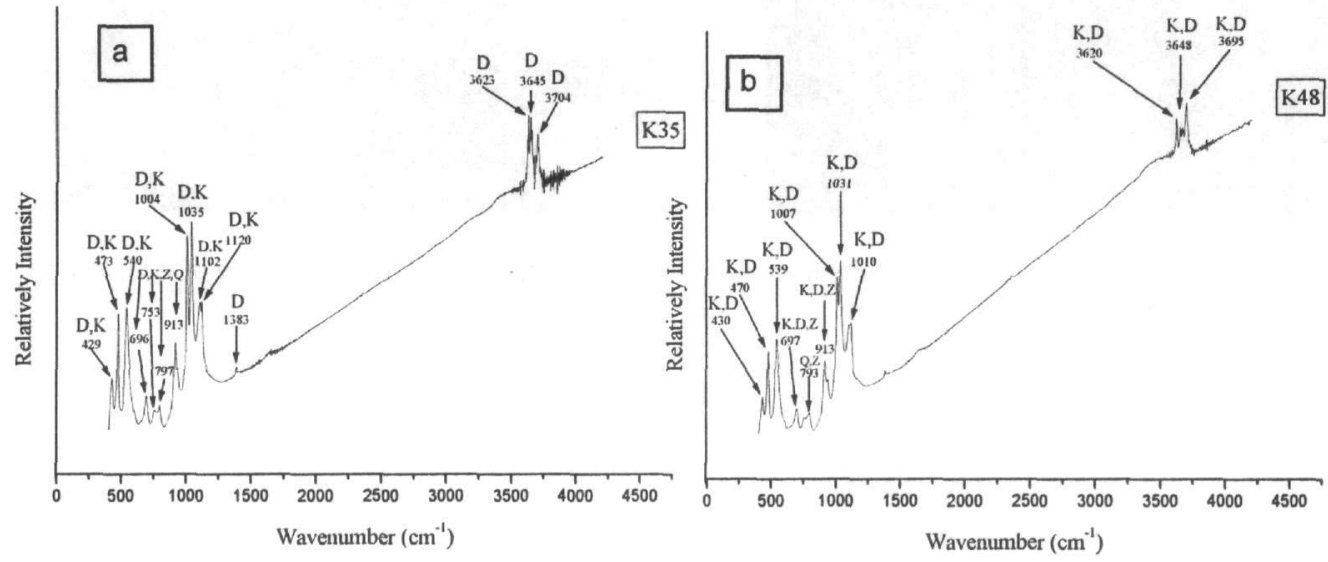

Figure 5. FTIR spectra of highly altered samples $\mathrm{K} 35$ (a) and $\mathrm{K} 48$ (b). $\mathrm{K}=$ kaolinite, $\mathrm{Q}=$ quartz, $\mathrm{D}=$ dickite, $\mathrm{Z}=$ zunyite. 


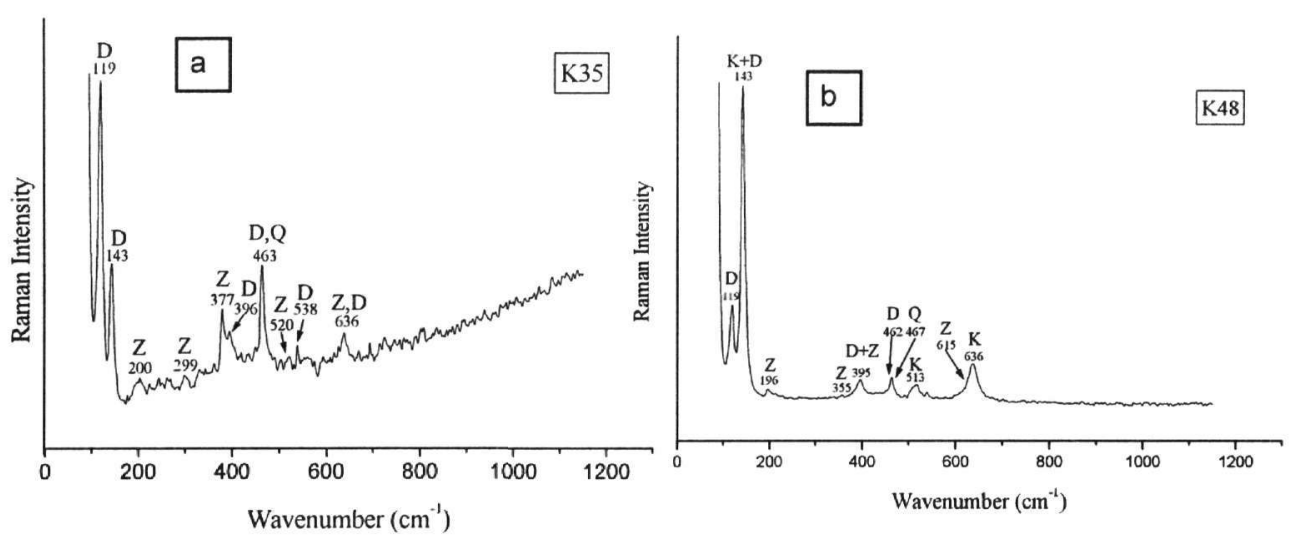

Figure 6. FT-Raman spectrum of the 100-1200 cm-1 region of highly altered rhyolitic rock from Kefalos (a) and Asfendiou (b). $Z=Z$ unyite, $D=$ dickite, $K=$ kaolinite, $Q=$ quartz.

\section{DISCUSSION}

The coexistence of zunyite, kaolinite, dickite and traces of pyrophyllite, is not feasible in a wide range of conditions. According to $\mathrm{Hsu}$ (1985) both $\mathrm{F}$ and $\mathrm{Cl}$ are indispensable to the formation of zunyite and yet higher $\mathrm{F}$ activities destabilize it. This assemblage reflects a late hydrothermal event, which resulted in advanced argilic alteration of rhyolites and a subsequent kaolin formation. According to Inoue (1995), Dill et al. (1997) and Willan \& Armstrong (2001) the assemblage Dickite + Zunyite + Quartz + Kaolinite \pm Pyrophyllite is stable at a temperature range between $250^{\circ} \mathrm{C}$ and $290^{\circ} \mathrm{C}$, at low $\mathrm{pH}(<3.5)$.

The occurrence of zunyite, in the kaolins of Kos island, implies incorporation of hydrothermal fluids rich in $\mathrm{F}^{-}$and $\mathrm{Cl}^{-}$, indicating also contamination by seawater. Zunyite typically coexists with dickite in some advanced argilic alteration zones (Dill et al. 1997, Sillitoe et al. 1998). Alunite is a common mineral in advanced argilic alteration zones and forms at similar conditions with zunyite. However, the formation of alunite requires hydrothermal fluids rich in $\mathrm{S}^{-2}$, hence the presence of alunite in trace amounts in Kos assemblages indicates the involvement of $S^{-2}$-poor hydrothermal fluids. Papoulis \& Tsolis-Katagas, (2001) argue that the advanced argilic alteration zone at Kefalos extends over small distances around faults. The alteration is presumably associated with these faults as the hydrothermal fluids were channeled along them.

\section{CONCLUSIONS}

Zunyite was found as an accessory mineral in highly altered rhyolitic rocks at Kefalos, southwestern Kos, and in a completely kaolinized rhyolitic dyke at Asfendiou, northeastern Kos. It is associated with dickite, kaolinite, quartz and pyrophyllite. Zunyite crystals, are up to $90 \mu \mathrm{m}$ in diameter but usually are less than $10 \mu \mathrm{m}$; the crystals are partly covered by kaolinite layers and their identification under SEM observation is based on their cubic crystal habit and EDX analyses. EDX analyses on the surface of zunyite revealed $\mathrm{Al}_{2} \mathrm{O}_{3} / \mathrm{SiO}_{2}$ values ranging from 2.6 to 2.7. FT-Raman spectra and XRD studies confirm also the presence of zunyite. The occurrence of zunyite suggests incorporation of hydrothermal fluids rich in $\mathrm{F}^{-}$and $\mathrm{Cl}^{-}$, thus indicating contamination by seawater. The presence, in trace amounts, of alunite, a mineral much more common than zunyite in hydrothermally altered formations, indicates that the hydrothermal fluids were poor in $\mathrm{S}^{-2}$. 
The frequent occurrence of zunyite in the altered felsic volcanic rocks of Kos reported here is thus indicative of unusual solution behavior during alteration.

\section{AGKNOWLEDGEMENTS}

The authors wish to thank Dr. G. Voyiagis of the Laboratory of molecular spectroscopy, Research Center of High Temperature and Chemical Processes, University of Patras, for his help with FTIR, FT-Raman and Raman spectroscopy and Mr. V. Kotsopoulos, of the Laboratory of Electron Microscopy and Microanalysis, University of Patras, for his help with the SEM photomicrographs. The first author is thankful to the State Scholarship Foundation of Greece for the financial support during his Ph.D. study.

\section{REFERENCES}

Baur W.H. \& Ohta T. 1982. The $\mathrm{Si}_{5} \mathrm{O}_{16}$ pentamer in zunyite refined and empirical relations for individual siliconoxygen bonds. Acta Crystallogr., B38, 390-401.

Boven A., Brousse R., Dalabakis P. \& Pasteels P. 1987. Geological and geo-chronological evidences on the evolution of KOS-JALI-NISYROS eruptive centres, Aegean arc, Greece. Terra Cognita, 7, 328-329.

Dalabakis P. 1987. La volcanisme recent de I i île de Kos. Thèse de doctorat, Paris. XI. 266p.

Dill H.G., Bosse R., Henning K-H. \& Fricke A. 1997. Mineralogical and chemical variations in hypogene and supergene kaolin deposits in a mobil fold belt the Central Andes of northwestern Peru. Miner. Deposita, 32, 149-163.

Gadsden J.A. 1975. Infrared Spectra of Minerals and Related Inorganic Compounds. Butterworths, London, 180p.

Hsu L.C. 1985. Stability relations of zunyite under hydrothermal conditions. Geol. Soc. Am., Abstract Programs 17/98. Annual meeting of the Geological Society of America.

Inoue A. 1995. Formation of Clay Minerals in Hydrothermal Environments. In: Velde B., (ed), Origin and Mineralogy of Clays, Clays and the Environment, 268-329p.

Kloprogge J.T. \& Frost R.L. 1999. Raman and infrared microscopy study of zunyite, a natural $\mathrm{Al}_{13}$ silicate. Spectrochimica Acta Part A, 55, 1505-1513.

Louisnathan S.J. \& Gibbs G.V. 1972. Aluminum-silicon distribution in zunyite. Amer. Mineral., 57, 1089-1108.

Papoulis D. 2003. Mineralogical study, kaolinitization processes and properties of kaolins from Leucogia, Drama and Kos Island. Ph. D Thesis, Univ. Patras, 289p.

Papoulis D. \& Tsolis-Katagas P. 2001. Kaolinization process in the Rhyolitic rocks of Kefalos, Kos island, Aegean sea, Greece. Bull. Geol. Soc. Greece, 34/3, 867-874.

Pauling L. 1933. The crystal structure of zunyite, $\mathrm{Al}_{13} \mathrm{Si}_{5} \mathrm{O}_{20}(\mathrm{OH}, \mathrm{F})_{18} \mathrm{Cl}$. Z. Kristallogr., 84, 442-452.

Sillitoe R.H., Steele B.G., Thompson J.F.H. \& Lang J.R. 1998. Advanced argillic lithocaps in the Bolivian tinsilver belt. Miner. Deposita, 33, 539-546.

Triantaphyllis M. 1994. Geological map of Greece, Western Kos (Kefalos) sheet, 1:50000, I.G.M.E., Athens.

Triantaphyllis M. 1998. Geological map of Greece, Eastern Kos sheet, 1:50000, I.G.M.E., Athens.

Turco G. 1962. La zunyite; recherches experimentales physico-chimiques en liaison avec l'etude du nouveau gisement deBeni-Embarek. Bull. Soc. Francaise Mineralogie et Cristallographie, LXXXV, 407-458.

Willan R.C.R. \& Armstrong D.C. 2001. Successive geothermal, volcanic-hydrothermal and contact metasomatic events in islands-arc basalts, South Shetland Islands. Durham meeting abstracts, 57-58.

Zagal'skaya $\mathrm{Yu}$. G. \& Belov N. 1964. Concerning the crystal structure of zunyite $\mathrm{Al}_{13}(\mathrm{OH})_{18} \mathrm{Si}_{5} \mathrm{O}_{20} \mathrm{Cl}=$ $\left[\mathrm{Al}_{12}(\mathrm{OH})_{18} \cdot \mathrm{SiO}_{4}\right] \cdot\left[\mathrm{Al}\left(\mathrm{SO}_{4}\right)_{4}\right] \mathrm{Cl}$. Sov. Phys. Crystallogr., 8, 429-432.

Zhou B. \& Sherriff B.L. 2003. Nuclear Magnetic Resonance study of Al:Si and F:OH order in zunyite. Can. Mineralogist, 41, 891-903. 